\title{
Seaweed susceptibility to herbivory: chemical and morphological correlates
}

\author{
Valerie J. Paul ${ }^{1} \&$ Mark E. Hay ${ }^{2}$ \\ 'Marine Laboratory, University of Guam, UOG Station, Mangilao, Guam 96923 \\ ${ }^{2}$ Institute of Marine Sciences, University of North Carolina at Chapel Hill, Morehead City, North Carolina 28557, USA
}

\begin{abstract}
The susceptibility of 82 species of tropical seaweeds to grazing by herbivorous fishes was assessed on 8 different coral reefs in the Florida Keys, USA. Most species were simultaneously assayed for the presence or absence of unusual secondary metabolites and recorded as having either calcified or uncalcified thalli. Both production of secondary metabolites and of a calcified thallus were associated with low susceptibility to herbivory. However, the relative importance of calcification versus chemical deterrents cannot be assessed for the calcified species since almost all these also contained secondary metabolites. Eighty-five \% of calcified species, but only $39 \%$ of uncalcified species, produced secondary metabolites. Secondary metabolites were produced by $71 \%$ of the species least susceptible to herbivory $(<25 \%$ eaten) but by only $20 \%$ of the species most susceptible to herbivory $(>75 \%$ eaten). Calcified thalli were produced by $50 \%$ of the lowest preference species but by only $9 \%$ of the highest preference species. Thus, several common reef seaweeds appear to resist herbivory by relying primarily on chemical deterrents (genera Dictyota, Dilophus, Stypopodium, Lobophora, Avrainvillea, and some Caulerpa species) but many appear to combine both chemical and morphological defenses (genera Penicillus, Halimeda, Rhipocephalus, Udotea, Amphiroa, and Galaxaura). We suggest that multiple defenses will be common among seaweeds on coral reefs since herbivore diversity is high and it is unlikely that any single defense will be effective against the many types of herbivores that encounter these plants. This may account, in part, for the diversity of secondary metabolites produced by some tropical seaweeds.
\end{abstract}

\section{INTRODUCTION}

Intense grazing by herbivorous fishes, and in some habitats sea urchins, has been shown to directly affect the species composition and abundance of seaweeds in tropical reef ecosystems (Randall 1961, 1965, Earle 1972, Ogden et al. 1973, Sammarco et al. 1974, Vine 1974, Wanders 1977, Ogden \& Lobel 1978, Hay 1981b, 1984a, Hay et al. 1983, Lewis 1985, in press). These herbivorous fishes demonstrate distinct feeding preferences in field and laboratory assays (Earle 1972, Tsuda \& Bryan 1973, Bryan 1975, Ogden 1976, Ogden \& Lobel 1978, Lobel \& Ogden 1981, Hay 1981a, b, 1984, Littler et al. 1983, Lewis 1985, Wolf 1985). Analyses of stomach contents also indicate that certain algae are often consumed while others are avoided by herbivorous fishes under natural foraging conditions (Hiatt \& Strassburg 1960, Randall 1967, Hobson 1974, Bryan 1975). Even in reef areas of highest grazing pressure (e.g. shallow, structurally complex, reef slopes; Hay $1981 \mathrm{a}, \mathrm{b}, 1984 \mathrm{a}, \mathrm{b}, \mathrm{Hay}$ et al. 1983), some species of macroalgae grow in abundance which suggests that they are defended from grazing.

Herbivory is a major factor selecting for chemical adaptation in terrestrial environments and has been extensively examined in these habitats (Whittaker \& Feeny 1971, Levin 1976, Harborne 1977, 1978, Rosenthal \& Janzen 1979, Fox 1981, Coley et al. 1985). In contrast, very little is known about the role of chemical defense in marine plant-herbivore interactions although hundreds of novel secondary metabolites have been isolated from marine algae (Faulkner 1984). Chemical adaptation has been hypothesized to play an important defensive role for marine algae growing in areas of high herbivory (Ogden \& Lobel 1978, Norris \& Fenical 1982, Hay 1984a), but the defensive functions of secondary metabolites in marine plants have rarely been experimentally addressed (McConnell et al. 1982, Paul \& Fenical 1983, Steinberg 1984, 1985). Although several authors have commented that many low preference algae are thought to contain unusual secondary metabolites, no prior studies have simul- 
taneously examined the chemical composition of tropical algae and their relative susceptibility to removal by herbivores. Previous studies similar to the one reported here (Ogden 1976, Hay 1981a, 1984a) have discussed herbivore preferences in relation to secondary metabolites reported in the chemical literature. These studies did not determine the presence of these compounds in the algal populations they used in their tests. Recent documentation of between-population variance in both types and quantities of compounds produced by a species suggests that chemical analyses need to be run on algae used in herbivory assays to ensure that general patterns reported in the literature hold for the algal populations tested (Paul 1985).

In this study of algal susceptibility to herbivorous fishes, we asked the following questions: (1) Do low preference algae produce secondary metabolites which may function as chemical defenses? Are these absent in preferred species of algae? (2) Does calcification play a defensive role in marine algae instead of, or in addition to, chemical defense? (3) Do species of algae show large between-reef variation in their susceptibility to grazers?

\section{METHODS}

Study site. This research was conducted on 8 different reefs in the Florida Keys during October and November 1983. Algae were collected from various reef habitats including seagrass beds, reef crests, forereef slopes, and deep sand plains ( 24 to $40 \mathrm{~m}$ depth). We collected species of algae available in these habitats and abundant enough to use in the preference trials. At each reef, feeding preference assays were conducted in areas with the greatest numbers of grazing fishes (usually the shallow reef slopes at a depth of 5 to $10 \mathrm{~m}$ ). Parrotfishes (Scaridae) and surgeonfishes (Acanthuridae) were the predominant grazers in all reef habitats where the preference trials were conducted.

Feeding preference assays. Susceptibility of different species of algae to grazing by herbivorous fishes was examined by weaving small ( 3 to $4 \mathrm{~cm}$ long) pieces of thalli, at $5 \mathrm{~cm}$ intervals, into a $0.5 \mathrm{~m}$ length of 3-strand polypropylene line that was then fastened to the reef slope ( $N=33$ to 40 ropes per study site). Thus, when an herbivorous fish encountered a rope, all species of algae should have been equally apparent and available. Grazing of the thalli on the rope was allowed to continue until there was a clear distinction between the most and the least susceptible plants. This resulted in exposure times of between 1.75 and $22.5 \mathrm{~h}$ for different reefs. At the end of an experiment, each species on each rope was recorded as either still pre- sent or totally consumed. Ropes were placed in the field only under calm conditions and were shaken before attachment to the reef to ensure that all species were securely attached. Small portions of consumed thalli became inaccessible to fish since they were between the strands of the rope; but these portions almost always showed the crescent shaped bite marks of herbivorous fishes. In addition, we watched the feeding trials on most reefs for ca $1 \mathrm{~h}$ and saw no loss of algae to any source other than herbivory.

These methods measure only the relative susceptibility of a species to being eaten by the herbivorous fishes present in the habitat. They do not differentiate among fish species and they do not yield preference data for any given species or type of fish.

Data were analyzed by contingency table analyses supplemented by Fisher's Exact Test for comparisons with small cell sizes.

Chemical analyses. Species of algae were collected and kept in seawater until extracted. Extractions were made as soon as possible after collection, but usually within $6 \mathrm{~h}$. Algae were blotted dry, cleaned of epiphytes, and extracted with a $1: 1$ mixture of dichloromethane and methanol. Generally, only 2 or 3 plants were extracted in a minimum volume of solvent (20 to $50 \mathrm{ml}$ ). The solvent was air evaporated in the shade. In addition, some algae were collected in larger quantities and frozen for subsequent chemical analyses.

Thin layer chromatography (TLC) was used to detect the presence or absence of unusual secondary metabolites in the algae. TLC is an effective and rapid method to determine if an alga contains unusual secondary metabolites (Touchstone \& Dobbins 1978. Norris \& Fenical 1986). Commercially available plastic-backed TLC plates were used in this study (silica gel 60 F254, 0.2 mm thickness, EM Reagents). Extracts of several algae were run on the same TLC plate. The developing solvent used was $1 \%$ methanol in dichloromethane. After the solvent front reached the top of the plate, the TLC was viewed under a small ultraviolet (UV) lamp to observe any UV activity. The plate was then sprayed with $50 \%$ sulfuric acid and heated to observe unusual color reactions. Colors are indicative of compounds decomposing and colors varying from red or purple to blue or black are commonly observed for many secondary metabolites (see Norris \& Fenical 1986 for an elaboration of the methods).

Although TLC has been proven to be a very effective method of detecting secondary compounds in the field, it gives little quantitative information about concentrations of metabolites or about the chemical nature of the compounds observed. Familiarity with a particular algal extract and the characteristic staining of certain metabolites can be useful in identifying known com- 
pounds. But for new species of algae the TLC tells very little about the chemical structure of new compounds. Further isolation and structural elucidation work is required to determine if the compounds are novel or biologically active.

Also, the methods used in this study are ideal only for the detection of organic-soluble compounds. Highly polar metabolites are not readily detected by these techniques and water-soluble metabolites are not detected at all. Highly unstable metabolites may not be detected by TLC because of their rapid degradation.

Some of the algal extracts were retained for subsequent analysis by proton nuclear magnetic resonance (NMR) spectroscopy. Proton NMR is an extremely valuable tool in the structural elucidation of natural products (Jackman \& Sternhell 1969). Known compounds can be readily detected and identified by NMR spectroscopy. Crude extracts can be effectively assessed for unusual metabolites that may be very polar or which, for other reasons, are not detected by TLC. Estimates of the concentrations of some of the secondary metabolites in extracts were made by proton NMR and are reported in the Appendix. These estimates are based on the intensity of the proton signals for the secondary metabolites relative to the primary metabolites (triglycerides, pigments, sterols) in the NMR. The estimates are good for relative comparisons between extracts but only approximate the actual concentrations in the organic extracts, and therefore the values are reported as factors of ten $(10 \%, 20 \%, 30 \%$, etc.).

\section{RESULTS}

The results of 12 feeding preference trials are presented in Fig. 1. The presence $(+)$ or absence $(-)$ of unusual secondary metabolites in each species of algae is summarized in Fig. 1 and a discussion of the TLC results for algae containing secondary metabolites is presented in the Appendix. The presence of secondary metabolites in the algae is correlated with low susceptibility to herbivory. For example, 25 species of low preference algae (arbitrarily defined as $<25 \%$ eaten) produced secondary metabolites while only 9 species did not. In contrast, only 4 species of high preference algae (>75\% eaten) produced secondary metabolites while 16 species did not. These results are significant $(p<0.001)$ by Contingency Table Analysis.

Most of these least preferred algae $(<25 \%$ eaten) are also calcareous, and calcification and unusual chemicals are both present in many of the seaweeds that are most resistant to herbivores. Table 1 shows the relation between calcification and secondary metabolites for the 70 species of seaweeds that we investigated. In each taxonomic group with enough species to run adequate tests, a significantly greater proportion of calcified than non-calcified species produce secondary metabolites (Table 1). Additionally, $50 \%$ of the low preference species ( $<25 \%$ eaten) were calcified while only $9 \%$ of the high preference seaweeds were calcified ( $p=0.003$, Fisher's Exact Test).

Patterns of grazing susceptibility for algae of intermediate preference ( 25 to $75 \%$ eaten) were similar to those discussed above. Algae with secondary metabolites were consumed at significantly lower rates $(\bar{X}=46 \%$ eaten) than algae without secondary metabolites ( $\bar{X}=59 \%$ eaten) on the 5 reefs with more than 1 species in each category (Wilcoxon's PairedSample Test, $p=0.05)$. Similarly, species of calcified algae were consumed at significantly lower rates $(\bar{X}=$ $44 \%$ eaten) than noncalcified algae ( $\bar{X}=57 \%$ eaten) in comparisons from 5 reefs (Wilcoxon's Paired-Sample Test, $p=0.05$ ). Carysfort Reef, Sand Key, and Alligator Reef were excluded from these analyses because each had an unacceptably low number of intermediate preference species with or without chemicals or calcification. Again, the presence of secondary metabolites and calcification were correlated for the intermediate preference algae.

Although most of the least preferred algae contained unusual secondary metabolites (Fig. 1 and Appendix), several species of low-preference algae were not observed to contain secondary metabolites. Sargassum sp. (Middle Sambo Reef), Codium decorticatum, Titanophora incrustans, Galaxaura oblongata (Molasses Reef), Galaxaura lapidescens, Eucheuma isiforme (Looe Key), Dictyospheria cavernosa (French Reef), Cladophora fuliginosa (Alligator Reef), and $\mathrm{Kal}$ lymenia limminghii (Carysfort Reef) all showed grazing losses of less than $25 \%$ yet no secondary metabolites were detected in extracts from these algae. In some cases, morphological defenses may explain the resistance of these algae to herbivores (Galaxaura species are calcareous and E. isiforme, Sargassum sp., $C$. decorticatum, and $D$. cavernosa are often considered to have a tough or leathery morphology) (Littler et al. 1983). It is also possible that secondary metabolites in some of these species may have been undetected because of their polar or unstable chemistries or because compounds we interpreted as primary metabolites may play a defensive role. The highly polar compounds would not appear as a distinct spot by TLC but would remain at the origin. However, even these polar metabolites, when present in moderate to high concentrations, should be detectable as a large spot at the origin of the TLC. They were not detected in our TLC analyses. Ceramium nitens showed bioactiv- 
SOMBRERO REEF $(6 \mathrm{~h})$

2 HALIMEDA OPUNTIA

3 HALIMEDA GOREAU:!

4 UDOTEA CYATHIFORMIS

5 UDOTEA FLABELLUM

7 HALIMEDA COPIOSA

8 AVRAINVILLEA LONGICAULIIS

9 DICTYOPTERIS MEMBRANACEA

10 CAULERPA PROLIFERA

11 CAULERPA CUPRESSOIOES

12 HALIMEOA NCRASSATA

13 CAULERPA LANUGINOSA

5 CAULERPA MEXICANA

6 GRACILARIA CYLINDRICA

AURENCIA CY INDRT

18 AURENCIA GEMMIFERA

19 HALYMENIA FLORESIA

20 CHONDRIA TENUISSIMA

21 SPYRIOIA FILAMENTOSA MIODLE SAMBO REEF (1.75h)

I PENICILLUS DUMETOSUS

2 PEN IMEDA PAPTAT

4 STYPOPODIUM ZONALE

5 SARGASSUM SP.

6 HAL MEDA SCABRA

7 GALAXAURA LAPIOESCENS

8 DIGENIA SIMPLEX

9 LAURENCIA INTRICATA

11 CAUERPA PACEMOSA

12 HYPNEA MUSCIFORMIS

13 CAULERPA SERTULARIDIDES

14 AYPNEA SPINELLA

SAND KEY (3.5h)

1 DICTYOTA CERVICORNIS

2 CERAMIUM NITENS

JODTEA SP

4 HALIMEDA OPUNTIA

5 TALIMEDA GOREAUT

6 PENICILLUS CAPITATUS

7 LAURENCIA POITE

8 AAURENCIA INTRICATA

9 DASYA BAILLOUVIANA

- SPYRIDIA FILAMENTOSA

CHAMPIA PARVULA

12 THALASSIA TESTUOINUM
INOIVIOUALS EATEN $(\%)$ SIGNIFICANTLY

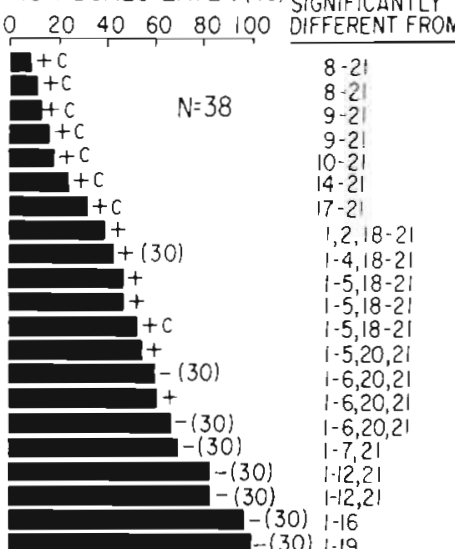

$\begin{array}{llllll}0 & 20 & 40 & 60 & 80 & 100\end{array}$

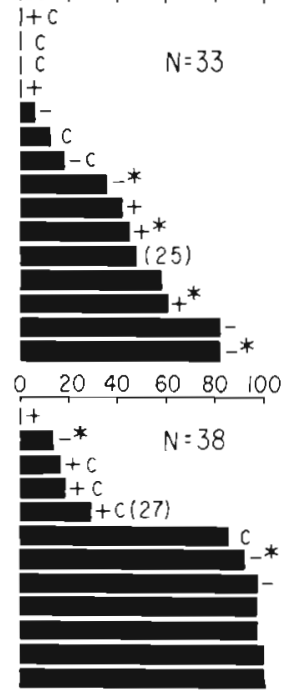

INOIVIOUALS EATEN $(\%)$

MOLASSES REEF (3h)

I LOBOPHORA VARIEGATA

2 UDOTEA CYATHIFORMIS

3 UDOTEA FLABELLUM

5 HALIMEDA GOREAUUI

6 CAULERPA PROLIFERA

7 MALIMEOA OPUNTIA

8 PENICILLUS CAPITATUS

9 PENICILLIUS OIMMETOSUS

10 OASYCLAOUS VERMICULARIS

12 HALIMEDA NCRASSATA

12 RICHOGLOEOPSIS PEDICELLATA

14 DIGENIA SIMPLEX

15 THALASSIA TESTUDINUM

16 CROUANIA ATTENUATA

17 SYRINGODIUM FILIFORME

18 GRACILARIA CERVICORNIS

19 CHONDRIA TENUISSIMA

20 LAURENCIA POITEI

MOLASSES REEF (2.5h)

HALIMEDA DISCOIDEA

2 HALIMEDA COPIOSA

3 LOBOPHORA VARIEGATA

4 GALAXAURA OBLONGATA

5 GALAXAURA OBLONGATA

7 SARGASSUM FILIPENDULA

8 CLADHYMENIA? LANCEIFOLIA

9 CAULERPA RACEMOSA

OO BOTRYOCL AOIA OCCIDENTALIS

I CHRYSYMENIA ENTEROMORPHA

12 THALASSIA TESTUDINUM

13 ANAOYOMENE SALOANHOE

MIDOLE SAMBO REEF ( $\mid 8 \mathrm{~h})$

AMPHIROA BRASILIANA

2 HALIMEDA SCABRA

4 DASYCLADUS VERMICULARIS

5 HALIMEDA DISCOIDEA

6 HALIMEDA INCRASSATA

6 UALOTEA CONGLUTINATA

8 IIAGORA FARINOSA

9 DICTYOTA SP

10 GALAXAURA LAFIDESCENS

11 LAURENCIA POITEI

12 CHONORIA TENUISSIMA

12 CERAMIUM SUBTILE

14 ACANTHOPHORA SPICIFERA

15 PADINA VICKERSIAE

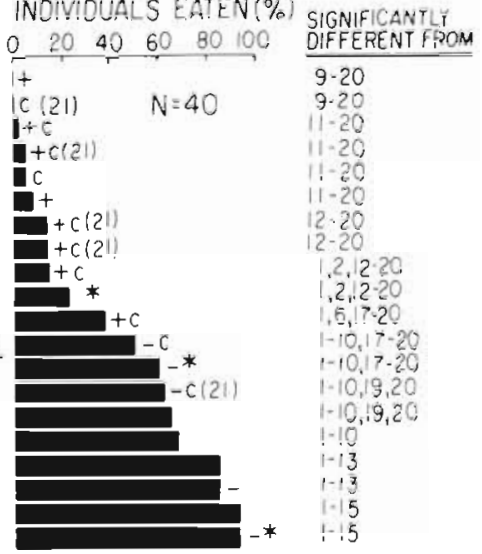

$0 \quad 20 \quad 40 \quad 60 \quad 80 \quad 100$
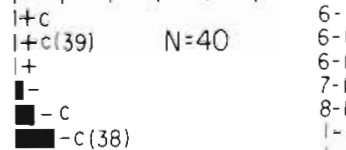

$2-13$

$6-13$

$8-13$

$-3,8-13$

$-4,10-13$

$-6,12,13$

$-6,12,13$

$-7,13$

$-7,13$
$-9,13$
$1-12$

-12
$-9,13$
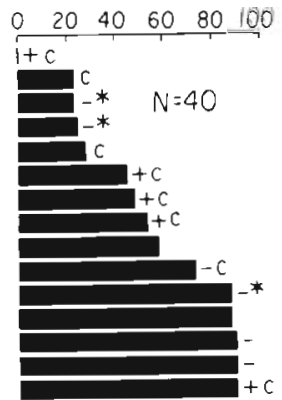

1. $7-15$

. $8=15$

$1,10-15$

$1,11-15$

$\cdot 3,1 \cdot 15$

1. $4,11-15$

1. 5

1. 9

1. 9

1. 9

1. 9

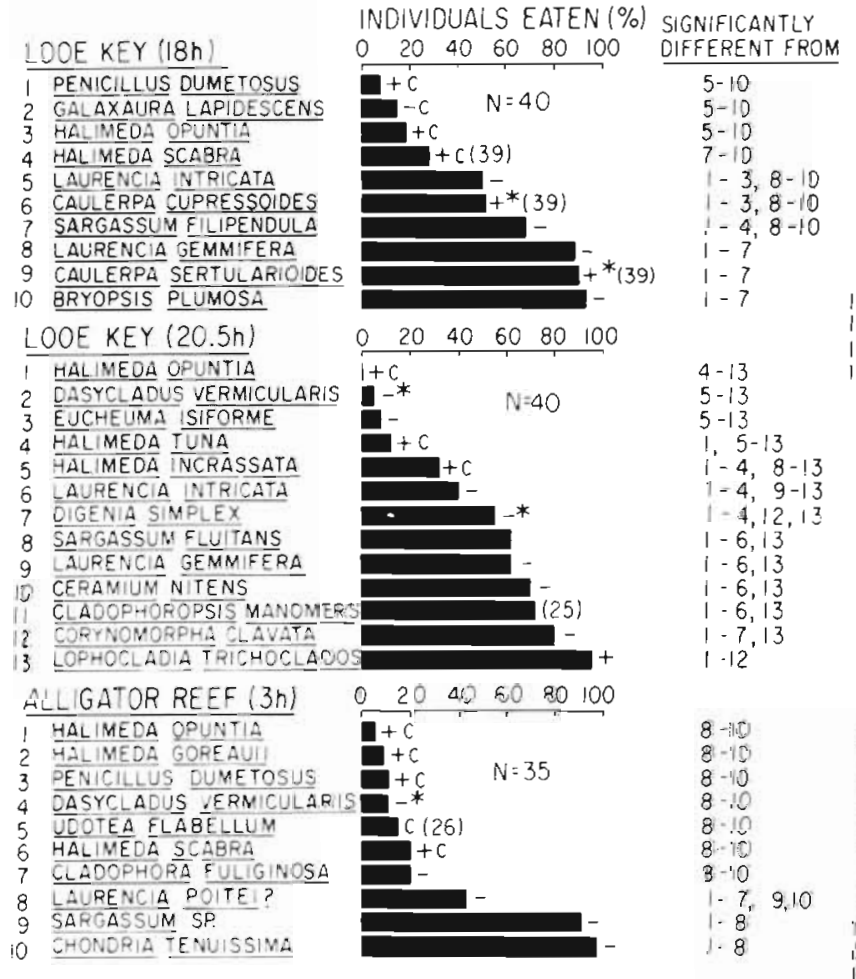

INDIVIDUALS EATEN (\%) SIGNIFICANTLY

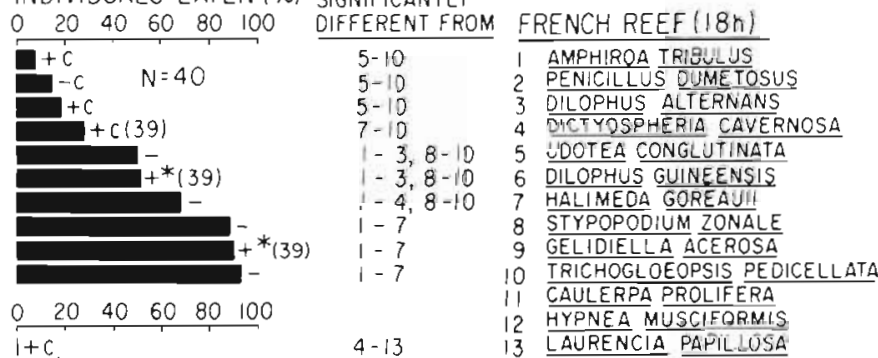

INDIVIDUALS EATEN(\%) SGMNFICANTLY $0 \quad 20 \quad 40 \quad 60 \quad 80100$ DIFFEAENT FROM

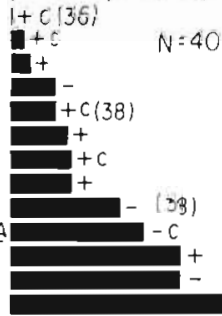
FRENCH REEF(19.5n)

HALIMEOA OPUNTIA

2 GALAXAURA OBLONGATA

3 HALIMEDA SCABRA

4 HALIMEDA GOREAUI:

5 HALIMEDA SP.

6 HALIMEDA SP

7 GALAXAURA CYLINDRICA

8 GALAXAURA RUGOSA

GALAXAURA LAPIDESCENS

CARYSFORT REEF (22.5h)

LOBOPHORA VARIEGATA

HALIMEDA OPUNTIA

KALLYMENIA LIMMINGHII

HALIMEDA OISCOIOEA

DICTYOTA DICHOTOMA

UDOTEA FLABELLUM

STYPOPOD

STOTEA CONG ZONALE

UOOTEA CONGLUTINATA

GALAXAURA OQLONGATA

HALIMEDA GOREAU!!

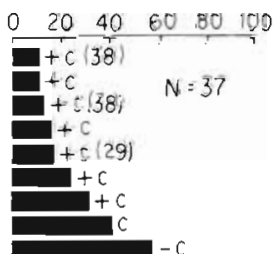

$\begin{array}{llllll}0 & 20 & 40 & 60 & 80 & 100\end{array}$

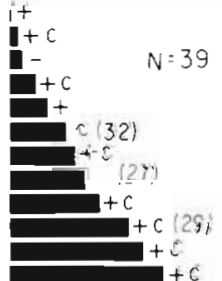

$2-13$

$2-13$

$1,10-13$
$1,10-13$

$1,10-13$

$1,10 \cdot 13$

10.13

- 3,13

$-8,13$
$-8,3$

$-8,13$

$-8,13$
-12

8,9

9
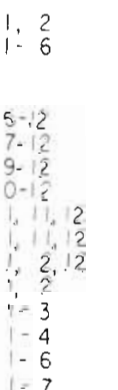
Table 1. Presence of secondary metabolites and calcification. The table shows the number of species of red, green, and brown algae in each category. P-values were determined by Fisher's Exact Test for red and green algae and by Contingency Table Analysis for total species. Brown algae were not analyzed due to the small number of species

\begin{tabular}{|lccc|}
\hline & $\begin{array}{c}2^{\circ} \\
\text { meta- } \\
\text { bolites }\end{array}$ & $\begin{array}{c}\text { No } 2^{\circ} \\
\text { meta- } \\
\text { bolites }\end{array}$ & P-value \\
\hline Red algae & & & \\
Calcified & 5 & 3 & $\mathrm{P}=0.007$ \\
Not calcified & 2 & 20 & \\
Green algae & 16 & 1 & $\mathrm{P}=0.040$ \\
Calcified & 8 & 5 & \\
Not calcified & & & \\
Brown algae & 1 & 0 & Not tested \\
Calcified & 7 & 2 & \\
Not calcified & & & \\
Total (all species) & 22 & 4 & $\mathrm{P}<0.001$ \\
Calcified & 17 & 27 & \\
Not calcified & & & \\
\hline
\end{tabular}

ity in antimicrobial and cytotoxicity tests of the methanol extracts from Sand Key and Middle Sambo Reef; however, the metabolites responsible for this bioactivity were not observable in the TLC (see Appendix). Additionally, water-soluble compounds like the coumarins reported from Dasycladus vermicularis (Menzel et al. 1983) would not be detected by our TLC assays.

Some species of algae that produced secondary metabolites were moderately to highly susceptible to herbivory. Several species of Caulerpa, Lophocladia trichoclados (Looe Key), Anadyomene saldanhoe (Molasses Reef), and Padina vickersiae (Sambo Reef) showed the presence of secondary metabolites by TLC yet were among the most rapidly consumed species in the preference trials. Of course there is no reason to assume that all unusual compounds serve as herbivore deterrents and direct testing of the deterrent effects of secondary metabolites is clearly warranted.

On each reef, different species of algae were usually used in the preference trials. This makes the data of

Fig. 1. Percentage of individuals completely consumed when transplanted into reef-slope habitats with high rates of herbivory. Symbols to right of histograms mean: + , unusual secondary metabolites detected by TLC; - , TLC showed no secondary metabolites; $C$, calcified species; ${ }^{\cdot}$ see Appendix for problems of interpretation; numbers in parentheses, sample size where different from that given for reef. Where neither + nor - appears, then this species was not analyzed by TLC at this site. Significant differences were evaluated by Contingency Table Analysis supplemented with Fisher's Exact Test for comparisons with some unacceptably small cell sizes. Numbers in parentheses by each reef name show duration of the assay limited value for evaluating between-reef variability in the reaction of herbivorous fishes to specific species. The tests were run for different periods of time on the different reefs and, in a sense, were selected for similar grazing rates by terminating the assays when most of the preferred species were consumed and before many of the least preferred species were consumed.

With these serious limitations in mind, it is still surprising that few species of algae showed very large between-reef differences in susceptibility to herbivorous fishes. Only 7 of 31 species assayed on multiple reefs showed consumption rates that differed by more than $30 \%$. These species are Caulerpa prolifera ( 8 to $70 \%$ eaten), Penicillus capitatus (0 to $85 \%$ eaten), Halimeda goreauii (5 to $54 \%$ eaten), Halimeda copiosa (0 to $32 \%$ eaten), Galaxaura lapidescens (15 to $58 \%$ eaten), Galaxaura oblongata ( 8 to $48 \%$ eaten), and Ceramium nitens (13 to $70 \%$ eaten). This between-reef variation may result from differences in feeding preferences of the fishes, differences in composition of the fish communities, differences in the intensity of grazing, or differences among reefs in the defensive characteristics of particular algal species.

TLC results did not show between-population differences in the kinds of secondary metabolites produced by a species on different reefs. However, differences in the concentrations of secondary metabolites could have occurred because TLC does not accurately detect concentration differences. Subsequent studies by proton NMR showed that some species of Caulerpa produced varying concentrations of caulerpenyne in collections from different reefs (see Appendix). Other studies have demonstrated high between-habitat variation in the concentrations of secondary metabolites in tropical green algae (Paul 1985).

\section{DISCUSSION}

The results of this study indicate a strong association between resistance to grazing by herbivorous fishes and the presence of unusual secondary metabolites and calcification. Almost all of the least preferred algae were found to produce both secondary metabolites and calcified thalli. It appears that both defensive chemistry and morphology have been selected for in areas of high grazing pressure on coral reefs.

The co-occurrence of secondary metabolites and calcification in most low preference algae compromises our ability to assess the importance of either chemical or morphological defenses alone. However, several species of low preference algae contained secondary metabolites but were not calcified. Since obvious morphological defenses were absent, these species most 
clearly suggest the defensive role of secondary metabolites. Lobophora variegata, Stypopodium zonale, Dilophus alternans, Dilophus guineensis, Dictyota cervicornis, Dictyota dichotoma, Avrainvillea longicaulis, and Caulerpa prolifera were relatively low-preference algae that possessed unusual secondary metabolites and were not calcified. Most of these algae have been chemically investigated and the results of these studies are summarized in the Appendix.

Additionally, recent studies on selected algal metabolites have shown that chemicals from some species of Dictyota, Stypopodium, Laurencia, Cymopolia, and Halimeda significantly reduce grazing when these compounds are coated onto palatable seaweeds and placed on reefs where they were exposed to grazing by a wide variety of reef fishes (Hay et al. unpubl., Hay \& Paul unpubl.).

The genus Caulerpa has been examined in several chemical studies and there appear to be some problems with the interpretation of the defensive roles of Caulerpa secondary metabolites. Species of Caulerpa produce the metabolites caulerpin (a dimerized indole derivative) and caulerpenyne (sesquiterpenoid) in variable concentrations (Doty \& Aguilar-Santos 1970, Amico et al. 1978, Maiti et al. 1978, Paul 1985). Caulerpenyne has been shown to be biologically active (antimicrobial, antineoplastic, ichthyotoxic, and feeding deterrent effects) in laboratory assays (McConnell et al. 1982, Hodgson 1984, Paul 1985). However, caulerpin appears to have little, if any, effect toward herbivores (McConnell et al. 1982) and shows no ichthyotoxicity in laboratory assays (Paul et al. unpubl.). Concentrations of caulerpenyne, and not caulerpin, should be considered when assessing the susceptibility of different species and populations of Caulerpa to herbivores.

The results presented in this study are only correlative and the absence of secondary metabolites in some grazer-resistant species and the presence of unusual secondary metabolites in some preferred species of algae indicate the need for critical experimental studies. Not all secondary metabolites produced by algae necessarily function as defenses against herbivores (caulerpin appears to be an example) and the testing of the extracts and isolated metabolites in biologically relevant assays is needed to determine which algal metabolites effectively deter herbivores.

Although the structure of herbivorous fish communities may vary between reefs and secondary metabolite production by some marine algae is variable (Paul 1985), we noted few differences in the susceptibility of most species to consumption by herbivorous fishes on different reefs. Similar patterns have also been noted by Hay (1984a). These observations sug- gest that different species of grazing fishes on different reefs show similar feeding preferences. Algal defensive characteristics may therefore be effective toward a broad range of generalist grazers.

This study contributes toward the mounting evidence that chemical defenses play a significant role in determining the food choices of herbivorous fishes. Morphological defenses alone do not appear to adequately defend most species of algae in areas of intense grazing as evidenced by the rarity of calcified species without secondary metabolites. Multiple defenses, secondary metabolites and calcification, are utilized by many grazer-resistant species. The need for calcified seaweeds to supplement this defense with secondary metabolites is not surprising since many reef herbivores, such as some scarids, are well adapted for the consumption of calcareous prey and up to $90 \%$ of the gut contents may be composed of calcium carbonate (Hiatt \& Strassburg 1960, Randall 1967). The need for seaweeds that produce compounds with strong biological activity also to calcify their thallus is less clear. This pattern may suggest that some herbivores with relatively weak mouth parts may be tolerant of the chemical defenses, thus selecting for calcification. Lubchenco \& Gaines (1981) have previously noted that any particular defense is likely to become less effective as a plant is subjected to attack by different types of herbivores. Thus, on tropical reefs where herbivores are both numerous and diverse, multiple defenses may prove to be the rule rather than the exception.

\section{APPENDIX}

\section{Notes on the TLC results of algal extracts}

\section{Rhodophyta}

Amphiroa brasiliana. TLC showed the presence of several UV active spots. The chemistry of this genus has not been previously investigated.

Amphiroa tribulus. TLC showed polar, UV active spots. Examination of the extract by proton NMR showed no interesting chemistry indicating that the compounds had probably degraded during storage. No previous chemical studies have been performed on this species.

Botryocladia occidentalis. The extract showed a UV active, polar spot, and antimicrobial and cytotoxic activity. Previous studies of $B$. occidentalis from central Florida showed the presence of indole-3-carboxaldehyde (V. Paul unpubl.).

Ceramium nitens. No unusual compounds were detected by TLC. However, methanol extracts showed antibiotic and cytotoxic activity in later tests of the algae collected at Sand Key and Middle Sambo Reef. 
This is an example of metabolites that may have been too polar for detection by our TLC techniques.

Digenia simplex. Our TLC methods detected no unusual metabolites. D. simplex has been reported to contain $\alpha$-kainic acid, a proline derivative which shows antihelminthic activity (Hashimoto 1979). This compound is highly polar, water-soluble, and thus may have been missed by our TLC technique.

Galaxaura cylindrica. A very large UV active spot was evident by TLC. Proton NMR showed that this was a mixture of unusual fatty acid-related compounds. The extract also showed antimicrobial activity. No chemistry has been previously reported from the genus Galaxaura.

Galaxaura oblongata. Chemistry was similar to $G$. cylindrica but compounds were present in lower concentrations.

Laurencia intricata. TLC results did not show the presence of secondary metabolites in algae from Sand Key, Sombrero Reef, or Looe Key. TLC of algae from Middle Sambo Reef showed the presence of several non-polar spots. L. intricata has been reported to contain halogenated sesquiterpenoids and non-terpenoid enynes (McMillan et al. 1974, White \& Hager 1978 , Cardellina et al. 1982).

Laurencia poitei. TLC results did not show the presence of secondary metabolites. However, L. poitei has been investigated from Florida and the compounds poitediol and poitediene have been reported (Fenical et al. 1978, Wright et al. 1983).

Liagora farinosa. Several UV active spots were observed by TLC. These may correspond to the acetylene-containing fatty acids previously reported from $L$. farinosa (Paul \& Fenical 1980).

Lophocladia trichocladus. TLC indicated a UV active, polar spot. Analysis by proton NMR indicated that this spot was a mixture of aromatic compounds. The extract also showed antimicrobial and cytotoxic activity.

\section{Phaeophyta}

Dictyopteris membranacea. TLC showed several UV active spots. $D$. membranacea has not been chemically investigated although the genus has been well studied and found to contain a variety of metabolites of mixed biogenetic origin (terpenoid and aromatic portions (Ochi et al. 1979, Gerwick 1981, Faulkner 1984).

Dictyota cervicornis. TLC showed the presence of several different secondary metabolites. The genus Dictyota has been extensively studied and contains a variety of terpenoid metabolites (Sun \& Fenical 1979, Gerwick 1981, Sun et al. 1981, Blount et al. 1982, Faulkner 1984).
Dictyota dichotoma. UV active, relatively polar spots were shown by TLC. The genus Dictyota has been extensively investigated (see references above).

Dilophus alternans. TLC showed the presence of many secondary metabolites that appear to be in large concentrations. D. alternans has no published investigations but has been found to be chemically active in collections from St. Croix, U.S.V.I. (W. Fenical unpubl.). The genus Dilophus has been chemically investigated and contains a variety of terpenoid metabolites which are often related to those found in Dictyota species (Kazlauskas et al. 1978, Gerwick 1981, Ochi et al. 1982, Ravi \& Wells 1982, Faulkner 1984).

Dilophus guineensis. Numerous secondary metabolites were indicated by TLC. This species has not been chemically investigated but the genus is well studied (see references above).

Lobophora variegata. TLC indicated the presence of polar metabolites. The polar and water-soluble extracts possessed potent antimicrobial and cytotoxic activity. Proton NMR indicates that the compounds may be related to phenolic lipids produced by Lobophora papenfussii from Palau (Gerwick \& Fenical 1982).

Padina vickersiae. TLC showed a polar purple-staining spot. This species has been studied and no unusual secondary metabolites were observed (Norris \& Fenical 1982)

Stypopodium zonale. TLC indicated the presence of the characteristic red-staining compounds stypoldione and stypotriol in collections from several different reefs (Gerwick \& Fenical 1981).

\section{Chlorophyta}

Anadyomene saldonhoe. TLC showed polar, UV active spots. A. saldonhoe has not been chemically investigated but $A$. stellata extracts are reported to possess cytotoxic activity (Targett \& Mitsui 1979, Hodgson 1984).

Avrainvillea longicaulis. TLC showed a polar UV active spot which corresponds to the known bioactive compound avrainvilleol (Sun et al. 1983).

Caulerpa cupressoides. TLC showed the presence of caulerpin (indole dimer) and caulerpenyne (sesquiterpenoid) in varying concentrations from different collections. Caulerpenyne varied from $0 \%$ (Middle Sambo) to $20 \%$ (Sombrero Key) of the organic extract. Caulerpenyne shows a wide spectrum of biological activity including antibiotic, antifungal, cytotoxic, antineoplastic, ichthyotoxic, and herbivore deterrent effects (Amico et al. 1978, McConnell et al. 1982, Hodgson 1984, Paul 1985). Caulerpin (indole dimer) is 
not as bioactive as caulerpenyne in laboratory bioassays (Doty \& Aguilar-Santos 1970, Maiti et al. 1978, McConnell et al. 1982, Paul et al. unpubl.).

Caulerpa lanuginosa. TLC showed the presence of caulerpenyne. Proton NMR confirmed that caulerpenyne was present as approximately $20 \%$ of the organic extract (see C. cupressoides).

Caulerpa mexicana. TLC showed the presence of caulerpenyne and NMR confirmed that caulerpenyne was present as about $10 \%$ of the organic extract (see C. cupressoides).

Caulerpa prolifera. TLC indicated the presence of caulerpenyne and caulerpin in varying concentrations from different reef collections. BY NMR, the concentrations of caulerpenyne varied from $20 \%$ of the organic extract in a Big Pine Key collection, $30 \%$ in a Sombrero Reef collection, to over $40 \%$ of the organic extract in a Molasses Reef collection (see C. Cupressoides).

Caulerpa racemosa. TLC indicated the presence of caulerpenyne and NMR confirmed that caulerpenyne was present as approximately $20 \%$ of the organic extract (see C. cupressoides).

Caulerpa sertularoides. TLC showed the presence of caulerpin, however, caulerpenyne was absent (see $C$. cupressoides).

Dasycladus vermicularis. This alga produces yellow, water-soluble substances when handled or extracted. These compounds are not evident by TLC because they are water-soluble, however, the aqueous extract showed antibiotic activity in laboratory assays. No organic-soluble secondary metabolites were apparent. These yellow compounds have been identified as coumarins (Menzel et al. 1983). Parrotfishes have been reported to graze on some species of the Dasycladales (Valet 1968).

Halimeda copiosa. TLC indicated the presence of the bioactive diterpenoid halimedatetraacetate (Paul \& Fenical 1984b). Proton NMR confirmed the presence of this metabolite in Sombrero reef collections as about $40 \%$ of the organic extract. In Molasses Reef collections, other unidentified diterpenoids were also observed by NMR.

Halimeda discoidea. ILC indicated the presence of halimedatetraacetate in relatively high concentrations (Paul \& Fenical 1984b). These results were consistent for the several collections of $H$. discoidea we examined.

Halimeda goreauii. UV active spots apparent by TLC. NMR showed the presence of a diterpenoid metabolite closely related to halimedatetraacetate (Paul 1985). This compound varied in concentration in different collections from 1 to $10 \%$ of the organic extract.
Halimeda incrassata. TLC showed the presence of halimedatetraacetate as the major metabolite. NMR confirmed the presence of the metabolite as about 20 to $40 \%$ of the organic extract in different collections. Halimedatrial was also present as a minor metabolite (Paul \& Fenical 1983, 1984b).

Halimeda opuntia. TLC indicated the presence of large concentrations of the bioactive metabolites halimedatrial and halimedatetraacetate in all collections (see references for $H$. incrassata).

Halimeda scabra. TLC indicated the presence of large concentrations of halimedatetraacetate in all collections. NMR confirmed this and showed that halimedatrial and epihalimedatrial were present as minor metabolites (Paul \& Fenical 1984b, Paul 1985).

Halimeda simulans. TLC showed the presence of halimedatetraacetate. NMR confirmed that the compound was present as about $20 \%$ of the extract (see $H$. copiosa).

Halimeda tuna. TLC showed the presence of halimedatetraacetate and halimedatrial in large concentrations (see references for $H$. incrassata).

Halimeda sp. TLC indicated the presence of halimedatetraacetate as the major metabolite. This was confirmed by NMR. The compound ranges in concentration from about $10 \%$ of the extract for a deep French reef collection to about $30 \%$ of the major metabolite as well as other minor metabolites from a reef slope collection at French Reef (Paul \& Fenical 1984b).

Penicillus capitatus. TLC showed non-polar, UV active spots. NMR confirmed the presence of bioactive compounds previously isolated from $P$. pyriformis (Paul \& Fenical 1984a, Paul 1985).

Penicillus dumetosus. TLC showed a non-polar, UV active spot characteristic of this alga. NMR of extracts from several reefs indicated the presence of the diterpenoid triacetate previously reported by Paul \& Fenical (1984a). Concentrations of the metabolite vary from 20 to $60 \%$ of the organic extract 10.2 to $0.8 \%$ dry weight) from different collections.

Rhipocephalus phoenix. TLC showed non-polar, UV active spots corresponding to the known compound rhipocephalin and other minor metabolites. Proton NMR confirmed the presence of rhipocephalin as up to $40 \%$ of the organic extract (about $1 \%$ of the dry weight). Rhipocephalin shows antibiotic, cytotoxic, ichthyotoxic, and feeding deterrent effects (Sun \& Fenical 1979, Paul 1985).

Udotea conglutinata. TLC showed the presence of a non-polar, UV active spot which may correspond to the known metabolite flexilin (Paul \& Fenical 1984a). These results were consistent from several collections. 
Udotea cyathiformis. TLC showed the presence of nonpolar, UV active spots corresponding to the known sesquiterpenoids from $U$. cyathiformis (Paul \& Fenical 1984a). NMR confirmed the presence of these bioactive compounds.

Udotea flabellum. TLC showed non-polar, UV active compounds corresponding to the bioactive metabolites udoteal and petiodial previously isolated from $U$. flabellum (Paul et al. 1982, Paul \& Fenical 1984a).

Udotea sp. TLC showed several UV active compounds in the extract. These may be related to some of the terpenoid metabolites previously identified in Udotea species (Paul \& Fenical 1984a).

Acknowledgements. We thank J. Norris and S. Fredericq for the identification of all algae used in this study. Critical review by $\mathrm{S}$. Nelson and 3 anonymous reviewers greatly improved this manuscript. This research was supported by the NOAA National Undersea Research Program and resulted from shiptime available on the RV Seahawk in OctoberNovember 1983

\section{LITERATURE CITED}

Amico, V., Oriente, G., Piatelli, M., Tringali, C., Fattorusso, E., Magno, S., Mayol, L. (1978). Caulerpenyne, an unusual sesquiterpenoid from the green alga Caulerpa prolifera. Tetrahedron Lett. 3593-3596

Blount, J. F., Duniop, R. W., Erickson, K. L., Wells, R. J. (1982). Two diterpenes with new carbocyclic ring systems from an Australian collection of the brown alga Dictyota dichotoma. Aust. J. Chem. 35: 145-163

Bryan, P. G. (1975). Food habits, functional digestive morphology, and assimilation efficiency of the rabbitfish Siganus spinus (Pisces, Siganidae) on Guam. Pacif. Sci. 29: 269-277

Cardellina, J. H., Horsley, S. B., Clardy, J., Leftow, S. R., Meinwald, J. (1982). Secondary metabolites from the red alga Laurencia intricata: Halogenated enynes. Can. J. Chem. 60: 2675-2677

Coley, P. D., Bryant, J. P., Chapin, F. S. III. (1985). Resource availability and plant antiherbivore defense. Science 230: 895-899

Doty, M. S., Aguilar-Santos, G. (1970). Transfer of toxic algal substances in marine food chains. Pacif. Sci. 24: 351-355

Earle, S. A. (1972). The influence of herbivores on the marine plants of Great Lameshur Bay, with an annotated list of plants. In: Collette, B. B., Earle, S. A. (ed.) Results of the Tektite program: ecology of coral reef fishes. Nat. Hist. Mus. LA County, Sci Bull. 14: 17-44

Faulkner, D. J. (1984). Marine natural products: metabolites of marine algae and herbivorous marine molluscs. Natural Products Rep. 1: 251-280

Fenical, W., Schulte, G., Finer, J., Clardy, J. (1978). Poitediol, a new nonisoprenoid diol from the marine alga Laurencia poitei. J. org. Chem. 43: 3628-3630

Fox, L. R. (1981). Defense and dynamics in plant-herbivore systems. Am. Zool. 21: 853-864

Gerwick, W. H. (1981). The natural products chemistry of the Dictyotaceae. Ph.D. dissertation, Scripps Institution of Oceanography, Univ. of California, San Diego
Gerwick, W. H., Fenical, W. (1981). Ichthyotoxic and cytotoxic metabolites of the tropical brown alga Stypopodium zonale (Lamouroux) Papenfuss. J. org. Chem. 46: 22-27

Gerwick, W. H., Fenical, W. (1982). Phenolic lipids from related marine algae of the order Dictyotales. Phytochem. 21: $633-637$

Harborne, J. D. (ed.) (1977). Introduction to ecological biochemistry. Academic Press, New York

Harborne, J. D. (ed.) (1978). Biochemical aspects of plant and animal coevolution. Academic Press, New York

Hashimoto, Y (1979). Marine toxins and other bioactive marine metabolites. Japan Societies Press, Tokyo, p. 228-229

Hay, M. E. (1981a). Spatial patterns of grazing intensity on a Caribbean barrier reef: herbivory and algal distribution. Aquat. Bot. 11: 97-109

Hay, M. E. (1981b). Herbivory, algal distribution, and the maintenance of between habitat diversity on a tropical fringing reef. Am. Nat. 118: 520-540

Hay, M. E. (1984a). Predictable spatial escapes from herbivory: how do these affect the evolution of herbivore resistance in tropical marine communities? Oecologia (Berl.) 64: $396-407$

Hay, M. E. (1984b). Patterns of fish and urchin grazing on Caribbean coral reefs: are previous results typical? Ecology $65: 446-454$

Hay, M. E., Colburn, T., Downing, D. (1983). Spatial and temporal patterns in herbivory on a Caribbean fringing reef: the effects on plant distribution. Oecologia (Berl.) 58: 299-308

Hiatt, R. W., Strasburg, D. W. (1960). Ecological relationships of the fish fauna on coral reefs of the Marshall Islands. Ecol. Monogr. 30: 65-127

Hobson, E. S. (1974). Feeding relationships of teleostean fishes on coral reefs in Kona, Hawaii. Fish. Bull. U.S. 72: 915-1031

Hodgson, L. M. (1984). Antimicrobial and antineoplastic activity in some south Florida seaweeds. Botanica mar. 27 : $387-390$

Jackman, L. M., Sternhell, S. (1969). Applications of nuclear magnetic resonance spectroscopy in organic chemistry. Pergamon Press, Oxford

Kazlauskas, R., Murphy, P. T., Wells, R. J. (1978). A series of new diterpenes from the brown alga Dilophus prolificans (Dictyotaceae). Tetrahedron Lett. 4155-4158

Levin, D. A. (1976). The chemical defenses of plants to pathogens and herbivores. Ann. Rev. Ecol. Syst. 7: 121-159

Lewis, S. M. (1985). Herbivory on coral reefs: algal susceptibility to herbivorous fishes. Oecologia (Berl.) 65: 370-375

Lewis, S. M. (in press). The role of herbivorous fishes in the organization of a Caribbean reef community. Ecol. Monogr.

Littler, M. M., Taylor, P. R., Littler, D. S. (1983). Algal resistance to herbivory on a Caribbean barrier reef. Coral Reefs 2: $111-118$

Lobel, P. S., Ogden, J. C. (1981). Foraging by the herbivorous parrotfish Sparisoma radians. Mar. Biol. 64: 173-183

Lubchenco, J., Gaines, S. D. (1981). A unified approach to marine plant-herbivore interactions. I. Populations and communities. Ann. Rev. Ecol. Syst. 12: 405-437

Maiti, B. C., Thomson, R. H., Mahendran, M. (1978). The structure of caulerpin, a pigment from Caulerpa algae. J. Chem. Res. (S): 126-127

McConnell, O. J., Hughes, P. A., Targett, N. M., Daley, J. (1982). Effects of secondary metabolites from marine algae on feeding by the sea urchin, Lytechinus variegatus. J. Chem. Ecol. 8: 1437-1453 
McMillan, J. A., Paul, I. C., White, R. H., Hager, L. P. (1974). Molecular structure of acetoxyintricatol: a new bromo compound from Laurencia intricata. Tetrahedron Lett. 2039-2042

Menzel, D., Kazlauskas, R., Reichelt, J. (1983). Coumarins in the Siphonalean green algal family Dasycladaceae Kutzing (Chlorophyceae). Botanica mar. 26: 23-29

Norris, J. N., Fenical, W. (1982). Chemical defense in tropical marine algae. In: Rutzler, K., MacIntyre, I. G. (ed.) Atlantic barrier reef ecosystem Carrie Bow Cay, Belize, scientific report 1: Structure and communities. Smithson. Contr. mar. Sci. 12: 417-431

Norris, J. N., Fenical, W. (1986). Natural products chemistry in benthic marine algae: uses in ecology and systematics. In Littler, M. M., Littler, D. S. (ed.) Handbook of phycological methods IV: Ecological field methods. Cambridge University Press, Cambridge

Ochi, M., Kotsui, H., Muraoka, K., Tokoroyama, T. (1979). The structure of Yahazunol, a new sesquiterpene-substituted hydroquinone from the brown seaweed Dictyopteris undulata Okamura. Bull. Chem. Soc. Japan. 52: 629-630

Ochi, M., Masui, N., Kotsuki, H., Miura, I., Tokoroyama, T. (1982). The structure of fukurinolal and fukurinal, two new diterpenoids from the brown seaweed Dilophus okamurai Dawson. Chem. Lett. 1927-1930

Ogden, J. C. (1976). Some aspects of herbivore-plant relationships on Caribbean reefs and seagrass beds. Aquat. Bot. 2: 103-116

Ogden, J. C., Brown, R. A., Salesky, N. (1973). Grazing by the echinoid Diadema antillarum Philippi: formation of halos around West Indian patch reefs. Science 182: 715-717

Ogden, J. C., Lobel, P. S. (1978). The role of herbivorous fish and urchins in coral reef communities. Environ. Biol. Fish. 3: $49-63$

Paul, V. J. (1985). The natural products chemistry and chemical ecology of tropical green algae of the order Caulerpales. Ph.D. dissertation, Scripps Institution of Oceanography, Univ. of California, San Diego

Paul, V. J., Fenical, W. (1980). Toxic acetylene-containing lipids from the red marine alga Liagora farinosa Lamouroux. Tetrahedron Lett. 21: 3327-3330

Paul, V. J., Fenical, W. (1983). Isolation of halimedatrial: Chemical defense adaptation in the calcareous reef-building alga Halimeda. Science 221: 747-749

Paul, V. J., Fenical, W. (1984a). Bioactive terpenoids from the Caribbean marine algae Penicillus and Udotea. Tetrahedron 40: 2913-2918

Paul, V. J., Fenical, W. (1984b). Bioactive diterpenoids from tropical marine algae of the genus Halimeda. Tetrahedron 40: 3053-3062

Paul, V. J., Sun, H. H., Fenical, W. (1982). Udoteal, a linear diterpenoid feeding deterrent from the tropical green alga Udotea flabellum. Phytochem. 21: 468-469

Randall, J. E. (1961). Overgrazing of algae by herbivorous marine fishes. Ecology 42: 812

Randall, J. E. (1965). Grazing effect on seagrasses by herbivorous reef fishes in the West Indies. Ecology 46 $255-260$
Randall, J. E. (1967). Food habits of reef fishes of the west Indies. Stud. Trop. Oceanogr. Miami 5: 655-847

Ravi, B. N., Wells, R. J. (1982). A series of new diterpenes from the brown alga Dilophus marginatus (Dictyotaceae). Aust. J. Chem. 35: 129-144

Rosenthal, G. A., Janzen, D. H. (ed.) (1979). Herbivores: their interaction with secondary plant metabolites. Academic Press, New York

Sammarco, P. W., Levinton, J. S., Ogden, J. C. (1974). Grazing and control of coral reef community structure by Diadema antillarum Philippi (Echinodermata: Echinoidea): a preliminary study. J. mar. Res. 32: 47-53

Steinberg, P. D. (1984). Algal chemical defense against herbivores: allocation of phenolic compounds in the kelp Alaria marginata. Science 223: 405-407

Steinberg, P. D. (1985). Feeding preferences of Tegula funebralis and chemical defenses of marine brown algae. Ecol Monogr. 55: 333-349

Sun, H. H., Fenical, W. (1979). Rhipocephalin and rhipocephanal: toxic feeding deterrents from the tropical marine alga Rhipocephalus phoenix. Tetrahedron Lett 685-688

Sun, H. H., Fenical, W. (1979). Hydroxydilophol, a new monocyclic diterpenoid from the brown alga Dictyota masonii J. org. Chem. 44: 1354-1356

Sun, H. H., McConnell, O. J., Fenical, W., Hirotsu, K., Clardy, J. (1981). Tricyclic diterpenoids of the dolastane ring system from the marine alga Dictyota divaricata. Tetrahedron 37: $1237-1242$

Sun, H. H., Paul, V. J., Fenical, W. (1983). Avrainvilleol, a brominated diphenylmethane derivative with feeding deterrent properties from the tropical green alga Avrainvillea longicaulis. Phytochem. 22: 743-745

Targett, N. M., Mitsui, A. (1979). Toxicity of subtropical marine algae using fish mortality and red blood cell hemolysis for bioassays. Phycologia 15: 181-185

Touchstone, J. C., Dobbins, M. F. (1978). Practice of thin layer chromatography. Wiley-Interscience, New York

Tsuda, R. T., Bryan, P. G. (1973). Food preferences of juvenile Siganus rostratus and S. spinus in Guam. Copeia 604-606

Valet, G. (1968). Contribution a l'etude des Dasycladales. Thesis, Univ. of Paris

Vine, P. J. (1974). The effect of algal grazing and aggressive behavior of the fishes Pomacentrus lividus and Acanthurus sohal on coral reef ecology. Mar. Biol. 24: 131-136

Wanders, J. B. C. (1977). The role of benthic algae in the shallow reef of Curaçao (Netherland Antilles). III. The significance of grazing. Aquat. Bot. 3: 357-390

White, R. H. Hager, L. P. (1978). Intricenyne and related halogenated compounds from Laurencia intricata. Phytochem. 17: 939-941

Whittaker, R. H., Feeny, P. (1971). Allelochemics: chemical interactions between species. Science 171. 757-770

Wolf, N. G. (1985). Food selection and resources partitioning by herbivorous fishes in mixed-species groups. Proc. 5th Int. Coral Reef Symp. 4: 23-28

Wright, A. E., Wing, R. M., Sims, J. J. (1983). Poitediene, a new metabolite from the marine red alga Laurencia poitei. Tetrahedron Lett. 24: 4649-4652 